\title{
Inflammatory Myofibroblastic Tumour of the Common Bile Duct
}

\section{Tumor Inflamatório Miofibroblástico da Via Biliar Principal}

\author{
Matilde ALMEIDA E SOUSA $\triangle^{1,2}$, Ana CARVALHO ${ }^{3}$, Raquel MEGA ${ }^{4}$, Tiago BILHIM ${ }^{1,2,5}$
}

Acta Med Port 2022 Oct;35(10):765-769 - https://doi.org/10.20344/amp.16976

\begin{abstract}
Inflammatory myofibroblastic tumour is a rare entity of indeterminate biological potential with a reduced tendency for recurrence and metastasis. Although it can arise from multiple organs, the bile duct is a very rare site of origin. We report the case of a 75-year-old asymptomatic male with elevated gamma-glutamyl transferase [1575 U/L (12 - $64 \mathrm{U} / \mathrm{L})]$ and alkaline phosphatase [271 U/L (40 - $150 \mathrm{U} / \mathrm{L})]$. Computed tomography showed a $17 \mathrm{~mm}$ hypervascular lesion in the confluence of the right and left hepatic ducts, with bile duct ectasia and right liver lobe atrophy. The patient was initially managed as having a Klatskin tumour and underwent right hepatectomy. Histology showed a spindle cell proliferation with an inflammatory infiltrate of lymphocytes, plasma cells and collagen-rich stroma, consistent with an inflammatory myofibroblastic tumour. He was discharged 30 days after admission, and nine months later remains asymptomatic. His liver function tests have normalized and follow-up tests are unremarkable.
\end{abstract}

Keywords: Bile Duct Neoplasms; Hepatic Duct, Common; Hepatectomy; Klatskin Tumour; Liver Function Tests

\section{RESUMO}

O tumor miofibroblástico inflamatório é uma entidade rara com comportamento biológico indeterminado e reduzido potencial de recorrência e metastização. Apesar de poder surgir em vários órgãos, as vias biliares constituem uma localização incomum. Descreve-se o caso de um homem de 75 anos, assintomático, com elevação da gama glutamil transferase [1575 U/L (12 - 64 U/L)] e fosfatase alcalina [271 U/L (40 - $150 \mathrm{U} / \mathrm{L})$ ], que realizou uma tomografia computorizada evidenciando uma lesão hipervascular com $17 \mathrm{~mm}$ na confluência dos ductos biliares, com ectasia das vias biliares intra-hepáticas à direita, e atrofia do lobo hepático correspondente. $\mathrm{O}$ caso foi abordado inicialmente como um tumor de Klatskin e realizada hepatectomia direita. A histologia relevou uma proliferação de células fusiformes com infiltrado inflamatório de linfócitos, plasmócitos e estroma rico em colágeno, compatível com tumor miofibroblástico inflamatório. Após nove meses, o doente permanece assintomático, com testes de função hepática com valores normais e sem sinais imagiológicos de recidiva.

Palavras-chave: Ducto Hepático Comum; Hepatectomia; Neoplasias dos Ductos biliares; Testes de Função Hepática; Tumor de Klatskin

\section{INTRODUCTION}

Inflammatory myofibroblastic tumours (IMT) were previously considered under the group of inflammatory pseudotumours, but now comprise a separate entity of fibroblastic/ myofibroblastic neoplasms with prominent inflammatory infiltrates and intermediate biological potential. ${ }^{1,2}$ These tumours are commonly seen in the lungs of children and young adults, but seemingly rare in other locations. ${ }^{1}$

We describe the case of an asymptomatic patient who presented with long-term elevation of gamma glutamyl transferase (GGT) and alkaline phosphatase (ALP), with no bilirubin elevation, caused by a hypervascular common bile duct lesion. The lesion was surgically removed and later shown to be an IMT.

\section{CASE REPORT}

We report the case of a 75-year-old male with incidental findings of altered hepatic function tests, particularly, raised gamma glutamyl transferase and alkaline phosphatase, associated with progressive bile duct ectasia. Bilirubin levels were normal and there were no signs or symptoms of disease.

An abdominal computed tomography (CT) detected an intraluminal hypervascular lesion located in the confluence of the right and left bile ducts. The lesion measured $17 \mathrm{~mm}$, showed prominent bile duct ectasia, particularly of the right hepatic ducts, and right lobe atrophy, along with thrombosis of the posterior branch of the right portal vein (Figs. 1, 2 and 3 ).

Blood tests showed gamma glutamyl transferase (GGT) levels of $1575 \mathrm{U} / \mathrm{L}(12-64 \mathrm{U} / \mathrm{L})$ and alkaline phosphatase (ALP) levels of $271 \mathrm{U} / \mathrm{L}(40-150 \mathrm{U} / \mathrm{L})$, with only slightly elevated alanine aminotransferase (ALT) of $98 \mathrm{U} / \mathrm{L}(0-55$ $U / L)$ and normal bilirubin levels of $0.90 \mathrm{mg} / \mathrm{dL}$. The tumour markers CA 19.9, CEA and alpha-fetoprotein were negative.

The patient remained asymptomatic until he was admitted for a right liver hepatectomy for suspected hilar cholangiocarcinoma, which was completed with no immediate complications. After one day in the intensive care unit, he was transferred to the surgical ward. Eleven days later,

1. Serviço de Radiologia. Centro Hospitalar Universitário Lisboa Central. Lisboa. Portugal.

2. Departamento de Anatomia e Imagiologia Clínicas. NOVA Medical School. Lisboa. Portugal

3. Serviço de Anatomia Patológica. Hospital Curry Cabral. Centro Hospitalar Universitário Lisboa Central. Lisboa. Portugal.

4. Unidade Hepato-bilio-pancreática. Hospital Curry Cabral. Centro Hospitalar Universitário Lisboa Central. Lisboa. Portugal.

5. Unidade de Radiologia de Intervenção. Hospital Curry Cabral. Centro Hospitalar Universitário Lisboa Central. Lisboa. Portugal.

$\triangle$ Autor correspondente: Matilde Almeida e Sousa. sousamatilde@campus.ul.pt

Recebido/Received: 07/08/2021 - Aceite/Accepted: 17/12/2021 - Publicado Online/Published Online: 07/02/2022 - Publicado/Published: 03/10/2022 Copyright (๑) Ordem dos Médicos 2022 


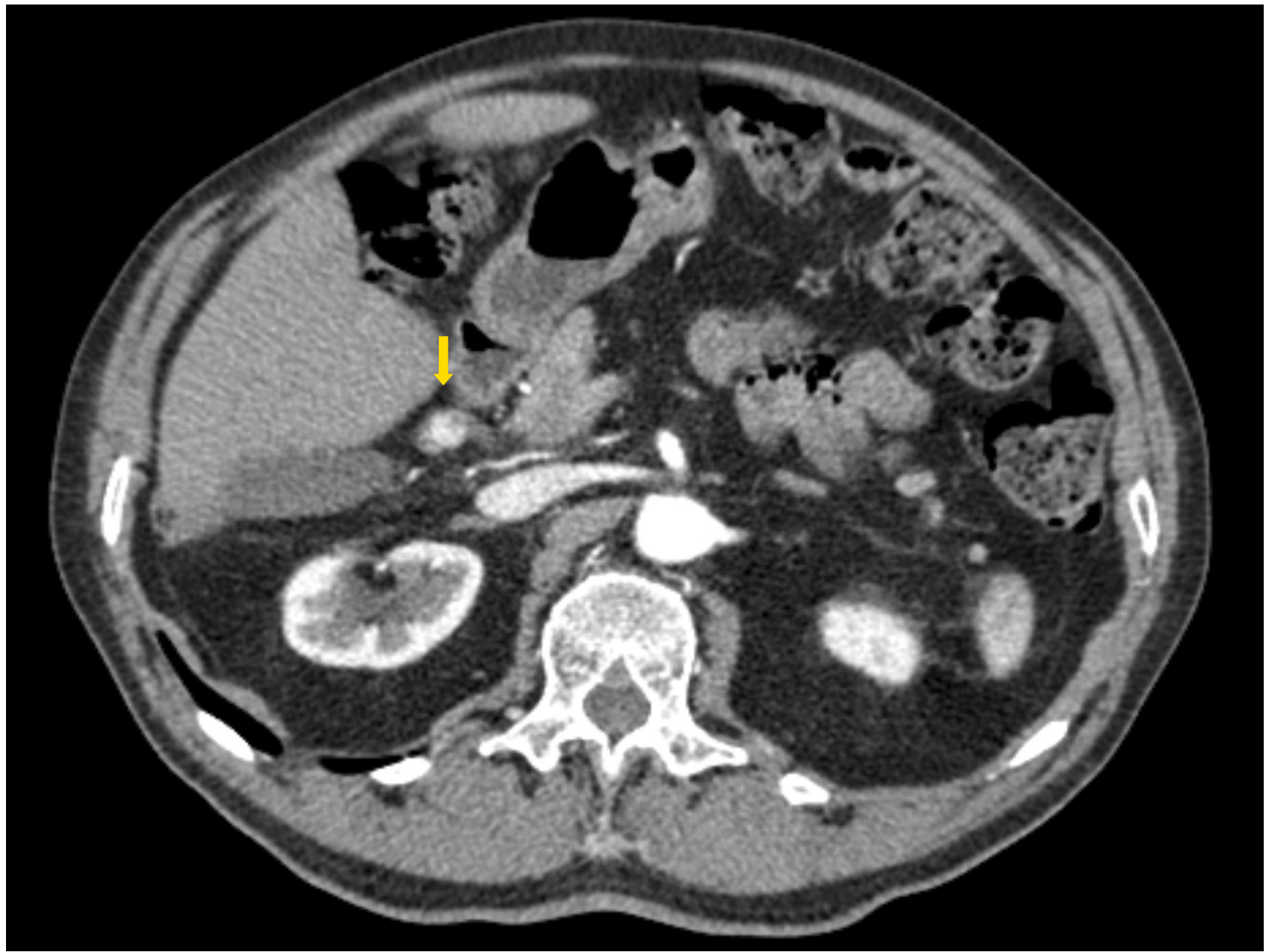

Figure 1 - Arterial phase CT showing a hypervascular lesion on the proximal common hepatic duct

there was a slight leukocyte elevation (from $9.1 \times 10^{\wedge} 9 / \mathrm{L}$ to $11.35 \times 10^{\wedge} \mathrm{g} / \mathrm{L}$ ), and therefore, a CT scan was performed. The scan showed a pneumoperitoneum and a collection along the line of the hepatectomy, consistent with a biloma. The patient underwent a second surgery to drain the collection and wash the abdomen. In addition, a biliary leak along the course of the hepatectomy was detected and promptly repaired. Although suspected, no dehiscence of the bilioenteric anastomosis was seen. The patient recovered well and was discharged 15 days after the second surgery, 30 days after admission.

Histologically, the lesion partially occluded the lumen of the bile duct and consisted of a mesenchymal tumour of epithelioid and spindle cells with vesicular nuclei, with a fascicular architecture immersed in a collagenous stroma, admixed with plasma cells and lymphocytes (Figs. 4 and 5). Mitotic activity was low, and no necrosis was present. The tumour cells did not express ACTIN, DESMIN, ALK or ROS 1. Although the immunohistochemistry pattern was not characteristic, the tissue samples were reviewed in a cancer centre and the tumour diagnosed as an inflammatory myofibroblastic tumour (IMT).

Nine months after admission, hepatic function tests normalized, follow-up tests were unremarkable and there was no bile duct ectasia.

\section{DISCUSSION}

Inflammatory myofibroblastic tumours are rare tumours of indeterminate biological potential, that can involve any anatomical location, with the lungs being the most affected site. The colon and small intestine are the most frequently involved gastrointestinal sites, but involvement of the biliary ducts is very uncommon with only a few reported cases. The etiopathogenesis of IMT in the bile ducts is not clear in the literature, with various reported theories, including prior infections or an autoimmune nature. ${ }^{3-5}$

IMTs predominantly affect children and young adults but have been described in any age. ${ }^{1,6}$ Site-specific symptoms have been described such as abdominal pain or gastrointestinal symptoms for intrabdominal lesions. Hepatic IMTs may present with abdominal pain, fever, biliary obstruction and/or portal hypertension due to obliterative phlebitis. An inflammatory syndrome consisting of fever, weight loss and malaise is seen in $15 \%-30 \%$ of patients. ${ }^{1,4,5}$

The reported imaging findings of IMT in the literature appear to be inconsistent and non-specific, probably due to its low incidence and its heterogeneous histopathologic features. As such, distinction from malignant neoplasms is often not possible. In general, hepatic lesions are wellcircumscribed with variable enhancement patterns, usually heterogenous or peripheral in the arterial phase..$^{4-7}$ 


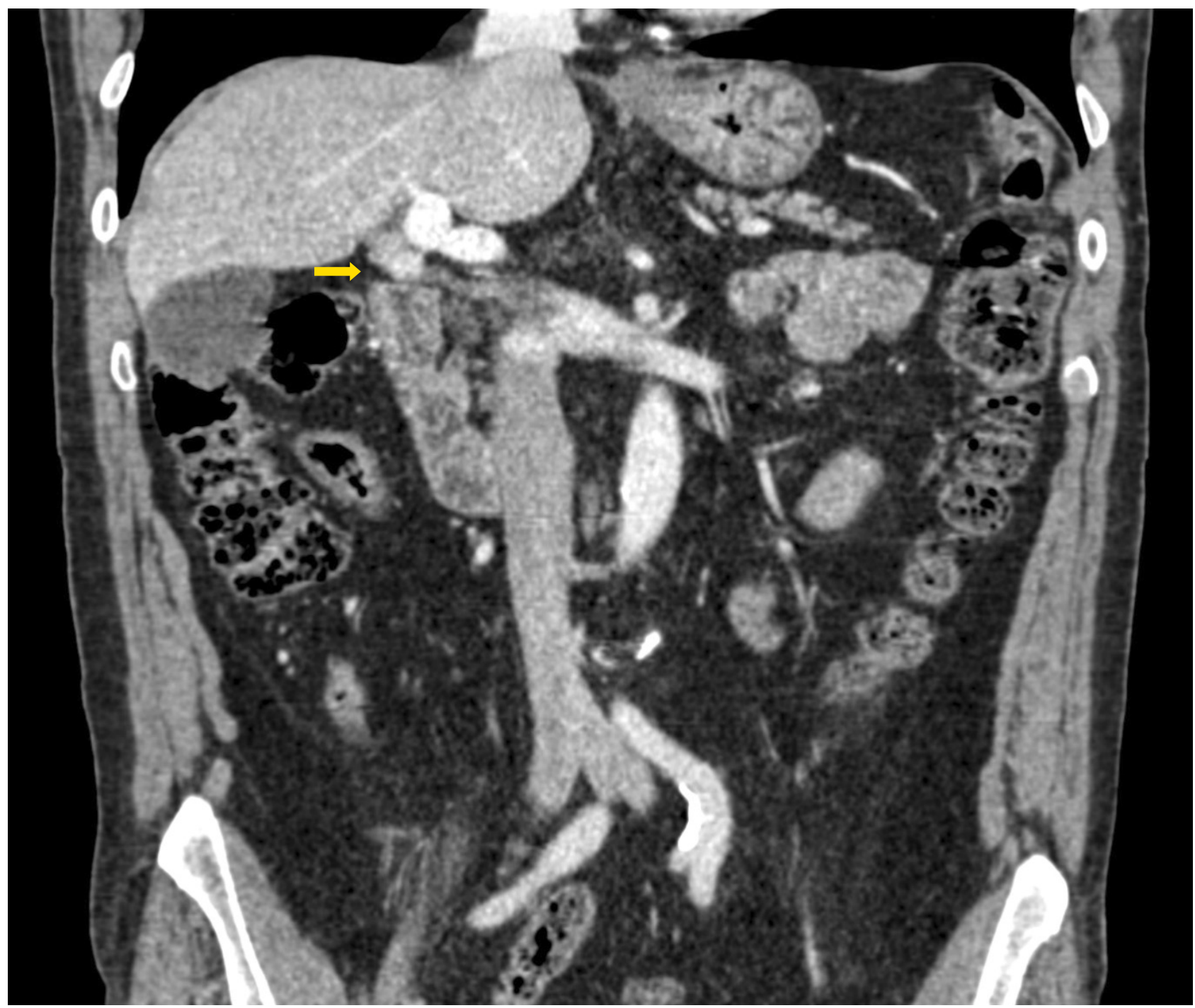

Figure 2 - Portal-venous phase coronal CT reconstruction showing persistent enhancement of the tumour on the proximal common hepatic duct, at the point of confluence of the left and right hepatic ducts

Brush cytology obtained by endoscopic retrograde cholangiopancreatography (ERCP) is frequently inconclusive, and therefore diagnosis is usually histological. Direct cholangioscopy with biopsy is an option. However, even if it shows signs of IMT, concerns regarding the adequacy of the samples are often raised. Therefore, a definitive diagnosis is usually based on analysis of postoperative material. ${ }^{8}$ Histological examinations usually reveal fascicles of cytologically bland spindle cells. The stroma may be myxoid or collagenous, usually containing an inflammatory infiltrate dominated by lymphocytes and plasma cells. Tumours can exhibit a compact fascicular architecture with minimal stroma or be sparsely cellular with a sclerotic stroma. Mitotic activity is low, and necrosis is usually absent. IMTs are positive for smooth muscle actin (SMA) in nearly all cases and can also express desmin and keratin. Nearly $60 \%$ of IMTs express ALK and $5 \%$ express ROS1.,2,9 However, immunohistochemistry is not essential to confirm the diagnosis, due to the variable expression of myofibroblastic markers. ALK positivity is helpful if present, but its absence does not exclude de diagnosis of IMT, especially in adults. ${ }^{1}$

The clinical course of IMTs is unpredictable. These tumours typically show a benign clinical behaviour, with slow growing, rarely metastasizing $(<5 \%)$ lesions, although recurrence rates for extrapulmonary IMT can be as high as $25 \% .{ }^{1,2,4}$

Complete surgical removal is the mainstay of treatment, although anti-inflammatory drugs and chemoradiotherapy have been used in some cases..$^{5,6}$ In advanced or unresectable IMTs with ALK immunoreactivity, specific tyrosine kinase inhibitors such as crizotinib can be considered as the standard of care. ${ }^{3,4}$ Regular long-term follow-up is required because of the tumour's recurring and metastasizing nature.

Due to the absence of specific symptoms or imaging features and extremely rare incidence, a diagnosis of IMT prior to surgery is challenging. In the present case, it was initially misdiagnosed as a Klatskin tumour due to its much higher occurrence and frequent perihilar location. However, there was a long history of altered hepatic functions tests, 


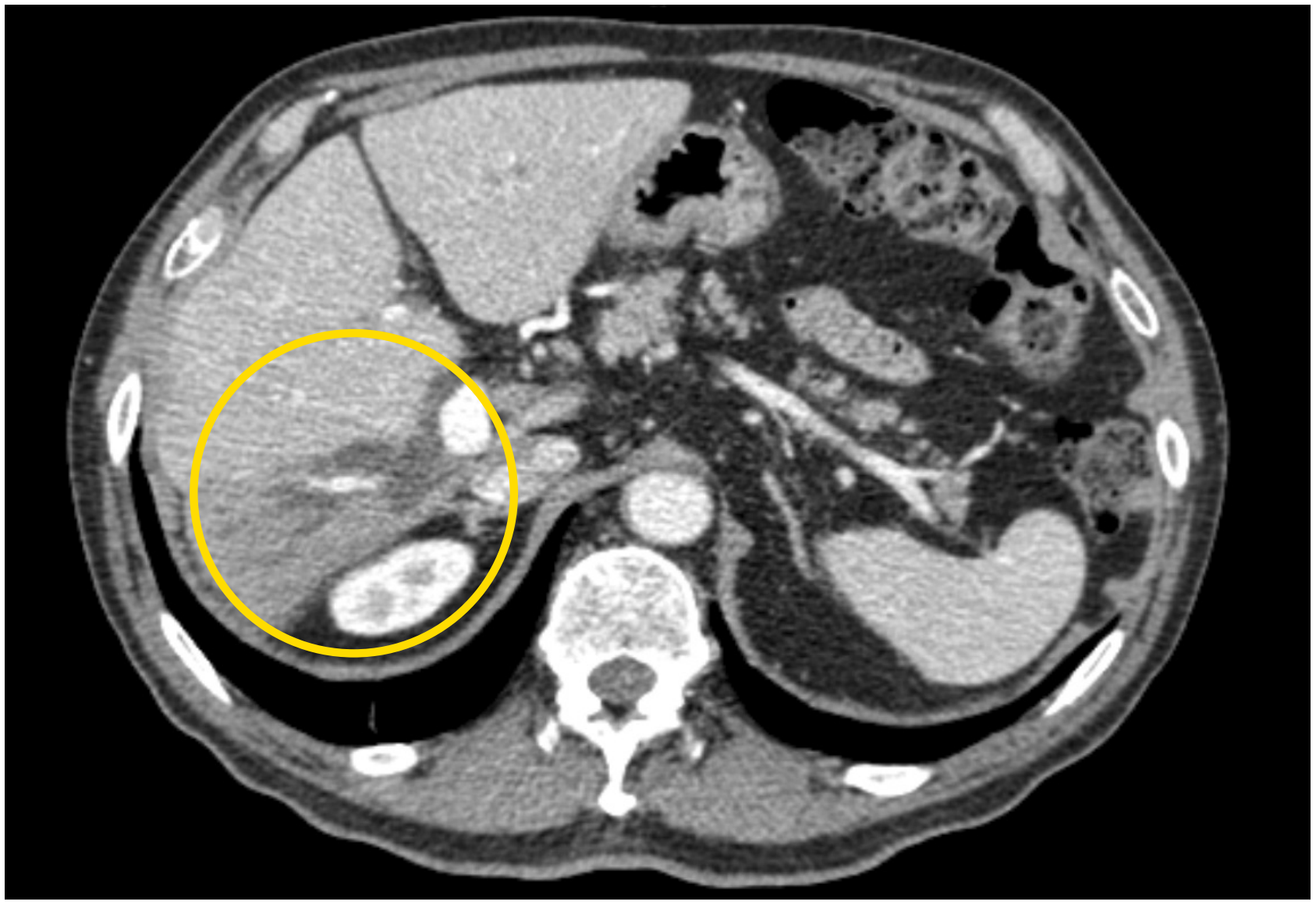

Figure 3 - Enhanced CT showing atrophy of the right hepatic lobe with compensatory hypertrophy of the left lobe, secondary to biliary obstruction by tumour

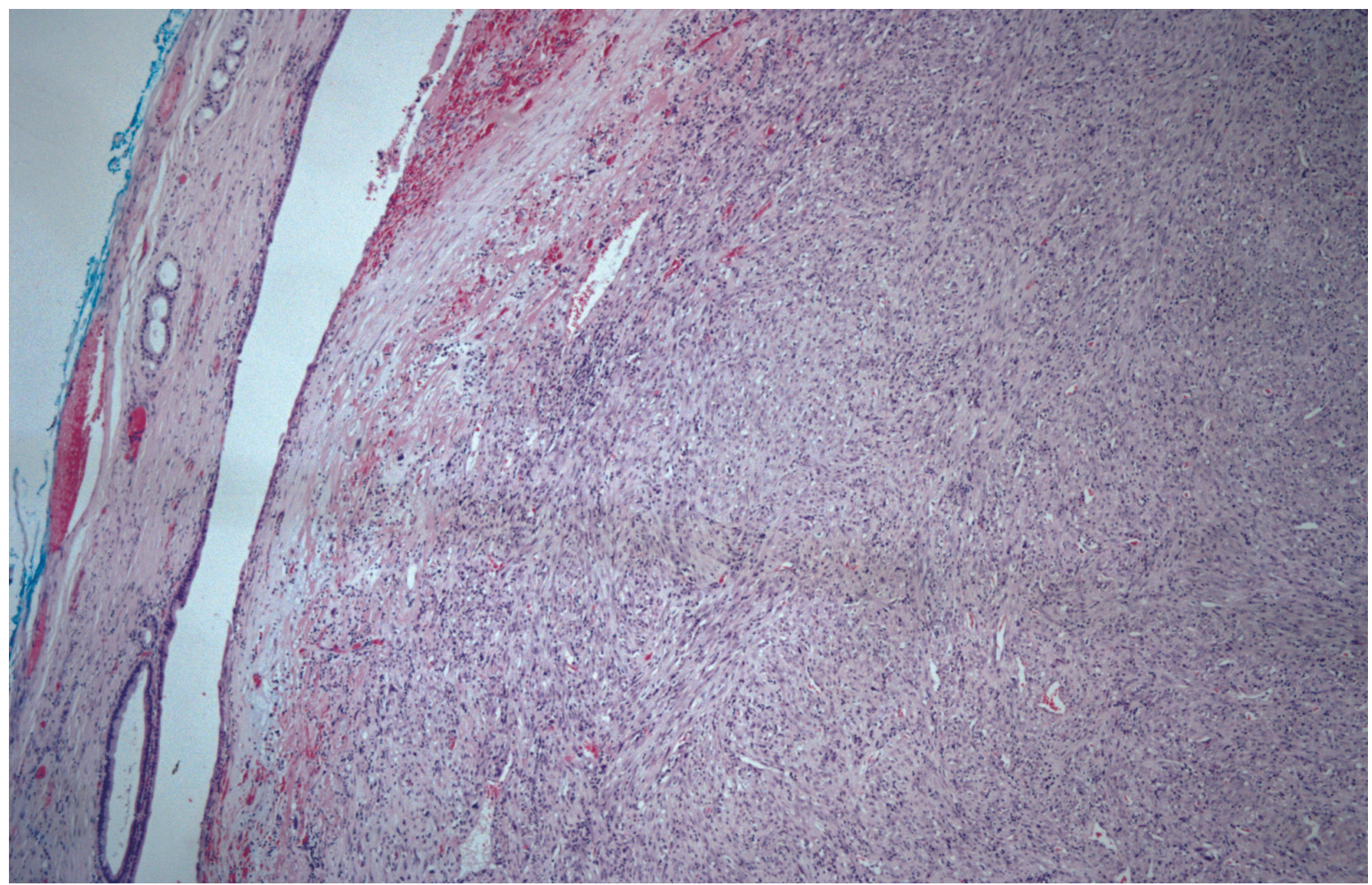

Figure 4 - Low power view of microscopic sample demonstrating a biliary duct occluded by a cellular spindle cell proliferation (HE - 40x) 


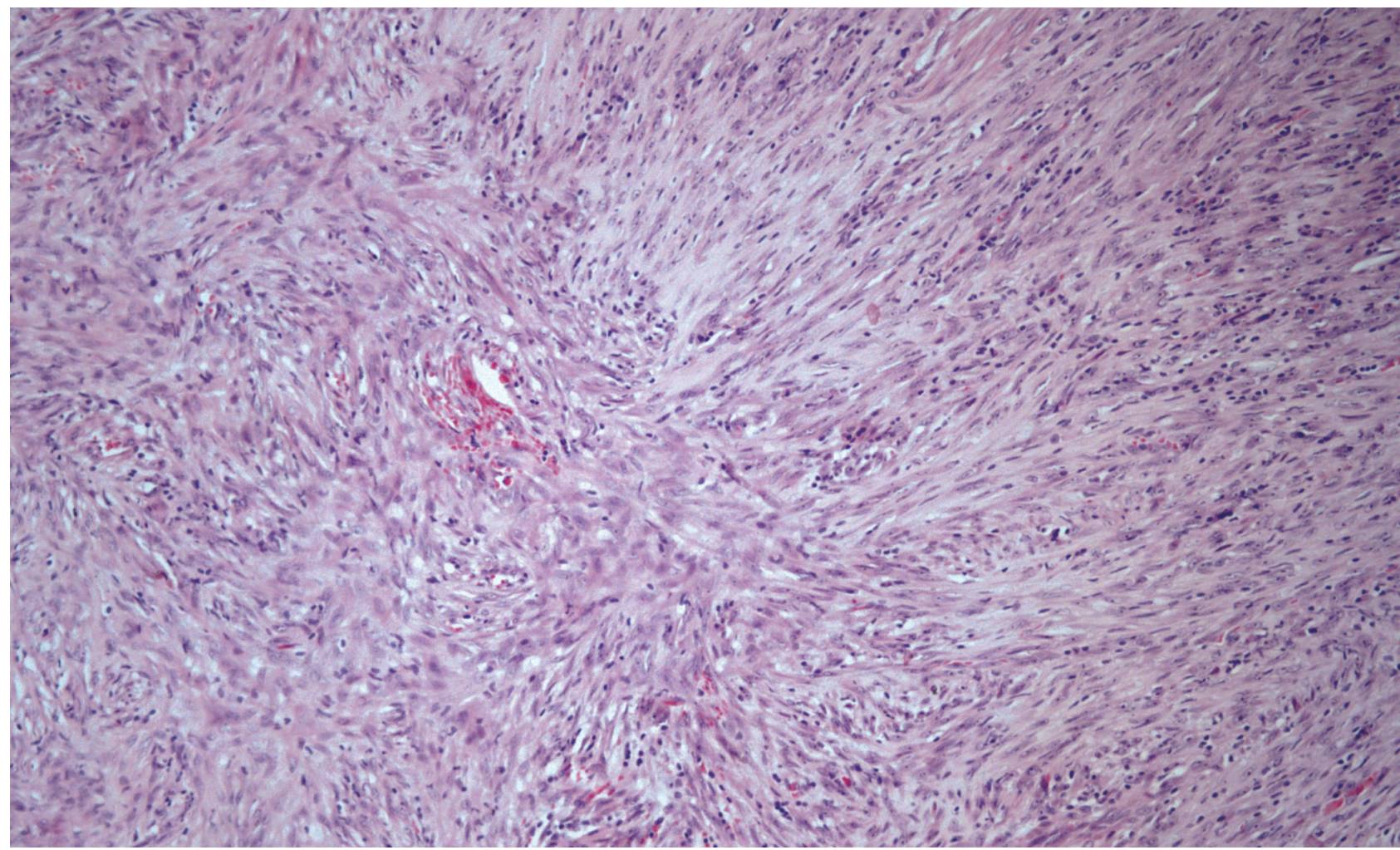

Figure 5 - Microscopic sample showing fascicles of spindle cells admixed with an inflammatory infiltrate (HE -100x)

which did not support an aggressive process, and the imaging features of hypervascularity and intraductal nature of the lesion were atypical of extrahepatic cholangiocarcinoma. These discrepant features, when present, may not be enough to establish the diagnosis of an IMT, but should raise suspicion of a diagnosis other than cholangiocarcinoma.

\section{AUTHORS CONTRIBUTION}

MAS: Research, draft of the paper.

AC, TB: Draft and critical review of the paper.

RM: Critical review of the paper.

\section{PROTECTION OF HUMANS AND ANIMALS}

The authors declare that the procedures were followed according to the regulations established by the Clinical Research and Ethics Committee and to the Helsinki Declaration of the World Medical Association updated in 2013.

\section{REFERENCES}

1. Gleason BC, Hornick JL. Inflammatory myofibroblastic tumours: where are we now?. J Clin Pathol. 2007;61:428-37.

2. WHO Classification of Tumours Editorial Board. Digestive system tumours. $5^{\text {th }}$ ed. Lyon: International Agency for Research on Cancer; 2019.

3. Verma R, Saha A, Saha K. Inflammatory myofibroblastic tumor of the mid common bile duct masquerading as cholangiocarcinoma. J Gastrointest Cancer. 2018;50:613-6.

4. Surabhi V, Chua S, Patel R, Takahashi N, Lalwani N, Prasad S. Inflammatory myofibroblastic tumors. Radiol Clin North Am. 2016;54:553-63.

5. Cantera J, Alfaro M, Rafart D, Zalazar R, Muruzabal M, Barquín P, et al. Inflammatory myofibroblastic tumours: a pictorial review. Insights

\section{DATA CONFIDENTIALITY}

The authors declare having followed the protocols in use at their working center regarding patients' data publication.

\section{PATIENT CONSENT \\ Obtained.}

\section{COMPETING INTERESTS}

The authors have declared that no competing interests exist.

\section{FUNDING SOURCES}

This research received no specific grant from any funding agency in the public, commercial, or not-for-profit sectors.

Imaging. 2014;6:85-96.

6. Rasalkar DD, Chu WC, To K, Cheng FW, Li CK. Radiological appearance of inflammatory myofibroblastic tumour. Pediatr Blood Cancer. 2010;54:1029-31.

7. Karimi M, Tizmaghz A, Shabestanipour G. An interesting case of inflammatory myofibroblastic tumor presenting as cholangiocarcinoma. Int J Surg Case Rep. 2018;47:38-40.

8. Strainiene S, Sedleckaite K, Jarasunas J, Savlan I, Stanaitis J, Studiene I, et al. Complicated course of biliary inflammatory myofibroblastic tumor mimicking hilar cholangiocarcinoma: a case report and literature review. World J Clin Cases. 2021;9:6155-69.

9. Weiss S, Goldblum J, Folpe A. Enzinger and Weiss's soft tissue tumors. $6^{\text {th }}$ ed. Amsterdam: Elsevier; 2014. 